\title{
Monoclonal antibody $\mathrm{Zt} / \mathrm{g} 4$ targeting $\mathrm{RON}$ receptor tyrosine kinase enhances chemosensitivity of bladder cancer cells to Epirubicin by promoting G1/S arrest and apoptosis
}

\author{
JUN-FENG CHEN ${ }^{1}$, BI-XIA YU ${ }^{1}$, RUI YU ${ }^{3}$, LIANG MA ${ }^{1}$, XIU-YI LV ${ }^{1}$, YUE CHENG $^{1,2^{*}}$ and QI MA ${ }^{1,2^{*}}$ \\ ${ }^{1}$ Translational Research Laboratory for Urology, ${ }^{2}$ Department of Urology, Ningbo First Hospital, The Affiliated Hospital of \\ Ningbo University, Ningbo, Zhejiang 315010; ${ }^{3}$ Department of Biochemistry and Molecular Biology, Zhejiang Key Laboratory \\ of Pathophysiology, School of Medicine, Ningbo University, Ningbo, Zhejiang 315212, P.R. China
}

Received June 27, 2016; Accepted November 21, 2016

DOI: 10.3892/or.2017.5356

\begin{abstract}
Epirubicin (EPI) is one of the most used intravesical chemotherapy agents after transurethral resection to nonmuscle invasive bladder tumors (NMIBC) to prevent cancer recurrence and progression. However, even after resection of bladder tumors and intravesical chemotherapy, half of them will recur and progress. RON is a membrane tyrosine kinase receptor usually overexpressed in bladder cancer cells and associated with poor pathological features. This study aims to investigate the effects of anti-RON monoclonal antibody $\mathrm{Zt} / \mathrm{g} 4$ on the chemosensitivity of bladder cells to EPI. After $\mathrm{Zt} / \mathrm{g} 4$ treatment, cell cytotoxicity was significantly increased and cell invasion was markedly suppressed in EPI-treated bladder cancer cells. Further investigation indicated that combing Zt/g4 with EPI promoted cell G1/S-phase arrest and apoptosis, which are the potential mechanisms that RON signaling inhibition enhances chemosensitivity of EPI. Thus, combing antibody-based RON targeted therapy enhances the therapeutic effects of intravesical chemotherapy, which provides new strategy for further improvement of NMIBC patient outcomes.
\end{abstract}

\section{Introduction}

Bladder cancer is a major cause of morbidity and mortality worldwide, and in the United States alone, 76,960 newly

Correspondence to: Professor Yue Cheng or Professor Qi Ma, Translational Research Laboratory for Urology and Department of Urology, Ningbo First Hospital, The Affiliated Hospital of Ningbo University, Ningbo, Zhejiang 315010, P.R. China

E-mail: yue.cheng@eyou.com

E-mail: qi.ma@eyou.com

"Contributed equally

Key words: RON, non-muscle invasive bladder tumors, epirubicin, chemosensitivity, cell cycle, cell apoptosis, proliferation and invasion diagnosed cases and 16,390 deaths are estimated in 2015 (1). Approximately $70 \%$ of patients with bladder cancer are non-muscle-invasive (NMIBC) at diagnosis (2). NMIBC is characterized by significant rates of recurrence and progression. The range of recurrence is $50-80 \%$, and progression $10-45 \%$, depending on disease risks (based upon grade, stage, and tumor size) (3). Transurethral resection of bladder tumor (TURBT) combined with intravesical chemotherapy is the primary method for treatment of NMIBC (4). The aim of intravesical chemotherapy is to decrease the possibility of tumor recurrence and progression. At present, Epirubicin (EPI), a derivative of doxorubicin, is one of the most used intravesical chemotherapy agents to treat NMIBC (5). Comparing with TURBT alone, EPI instillation after TURBT decreased nearly half of recurrence and progression of NMIBC (6). Although intravesical EPI chemotherapy has improved the clinical outcome of patients with NMIBC, efforts to potentiate drug action and enhance chemosensitivity should be investigated for further improvement of patient outcomes (7).

Recepteur d'origine Nantais (RON) belongs to the MET proto-oncogene family (8). The expression of RON is highly altered in many primary cancer samples including colon, breast and bladder cancer, and has prognostic value in predicting patient survival and clinical outcome (9-11). Aberrant RON activation, featured by overexpression of RON protein (12-14), isoform generation (15-17), and persistent activation of downstream signaling pathways (18), has been found in various types of cancers. Those aberrations contribute to tumorigenic phenotype, malignant progression and chemoresistance $(9,11,19)$. Due to the importance of RON in cancer pathogenesis, targeting RON signal pathway has therapeutic potential. Currently, various approaches including therapeutic monoclonal antibodies (mAb), siRNA and small molecule inhibitors (SMI) have been evaluated to inhibit RON signaling (20-22). Results from these studies demonstrate that inhibition of RON signaling contributes to reduced cell growth, diminished cell invasiveness, and impaired tumor metastasis. Combining RON signaling inhibition and chemotherapy agents were also under investigation in treating with various cancers. In colon cancer, $5-\mathrm{Fu}$ in combination with RON specific $\mathrm{mAb} \mathrm{Zt} / \mathrm{f} 2$ has been showed to markedly improve treatment effects (20), suggesting 
that inhibiting RON pathway may enhance chemosensitivity of chemotherapy drugs.

In bladder cancers, $\mathrm{RON}$ is overexpressed in more than $35 \%$ of samples $(11,14)$. RON expression has been documented in RT4, TCCSUP, UB09 and other bladder cancer cell lines (11). Overexpression of RON was associated with poor clinical outcome $(11,23)$. Furthermore, MSP, the only known ligand of RON, was also detected in human urine samples (11). These findings suggested that RON plays a role in bladder cancer tumorigenesis and invasion. Evidence has indicated that $\mathrm{RON}$-specific mAbs such as $\mathrm{Zt} / \mathrm{g} 4$ and $\mathrm{Zt} / \mathrm{f} 2$ rapidly induce RON internalization by cancer cells, which diminish RON signal transduction and enhance cytotoxic drug delivery and sensitivity (20,24-27). Thus, RON-specific mAbs are potentially effective approach to RON signal inhibition and enhancement of chemosensitivity.

In the present study, we selected a mouse $\mathrm{mAb} Z \mathrm{Zt} / \mathrm{g} 4$ highly specific to the RON extracellular domain to induce RON internalization and subsequent RON signal pathway inhibition. EPI was used as chemotherapeutical agent to determine the effects of RON on chemosensitivity in bladder cancer cells. This study provides new strategy to reduce NMIBC recurrence and progression.

\section{Materials and methods}

Cell lines and cell culture. The human 5637, T24, RT4, J82, UMUC and BIU87 bladder cancer cell lines were purchased from the Shanghai Institute of Cell Biology, Chinese Academy of Sciences (Shanghai, China). The cells were cultured at $37^{\circ} \mathrm{C}$ in a humidified atmosphere of $5 \% \mathrm{CO}_{2}$ in RPMI-1640 medium supplemented with $10 \%$ (v/v) fetal bovine serum (FBS), $2 \mathrm{mM}$ L-glutamine and $100 \mathrm{U} / \mathrm{ml}$ penicillin. The medium was replaced every 3 days.

Main reagents. EPI was purchased from the Hisun Pharmaceutical Co., Ltd. (Zhejiang, China). Cell Counting Kit- 8 (CCK-8) was purchased from Dojindo Molecular Technologies (Rockville, MD, USA). Mouse $\mathrm{mAb} \mathrm{Zt} / \mathrm{g} 4$ specific to RON sema domain and rabbit antibody (R5029, specific to the RON C-terminal peptide) were kindly supplied by Professor Yao (Laboratory of Cancer Biology and Therapeutics, First Affiliated Hospital, Zhejiang University School of Medicine). Rabbit anti-Bcl-2, anti-Bax, anti-Erk1/2, anti-AKT, anticaspase-3, anti-cyclin D1, anti-CDK4, anti-CDK6 and anti-p27 antibodies were from Cellular Signaling Technology (Danvers, MA, USA). FBS, RPMI-1640, L-glutamine and penicillin were purchased from Life Technologies Inc. (Carlsbad, CA, USA).

Western blotting. Western blot analysis was performed to measure the expression levels of various proteins in cells. Each sample equivalent of $100 \mu \mathrm{g}$ total proteins were electrophoresed in $8 \%$ SDS-PAGE and blotted on a nitrocellulose membrane (Millipore Inc., Billerica, MA, USA). Blots were blocked at room temperature for $2 \mathrm{~h}$ in $1 \mathrm{X}$ Tris-buffered saline (TBS) buffer, and then incubated with primary antibodies specific to Ron, $\mathrm{Bcl}-2$, Bax and $\beta$-actin overnight at $4^{\circ} \mathrm{C}$, respectively. After three washes for $3 \times 10 \mathrm{~min}$ in TBST, the membrane was incubated with horseradish peroxidase (HRP)-conjugated antimouse or anti-rabbit immunoglobulin $\mathrm{G}$ at room temperature

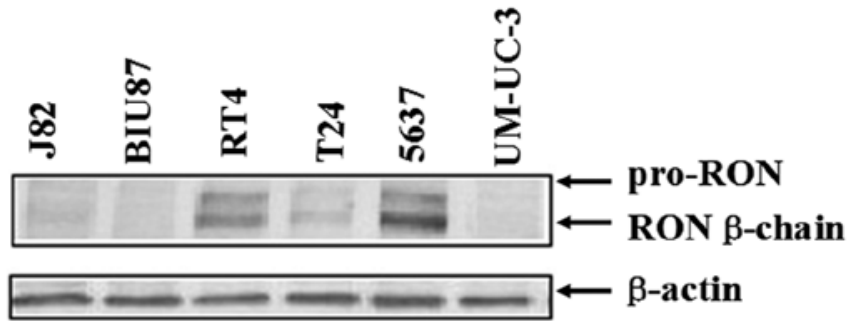

Figure 1. Expression of RON receptor proteins in various bladder cancer cells. Three bladder cancer cell lines including 5637, T24 and RT4 cell lines expressed a mature form of RON chain $(150 \mathrm{kDa})$ and a precursor RON (180 kDa), while the three bladder cancer cell lines J82, BIU87, UM-UC-3 had no RON expression.

for $1 \mathrm{~h}$. Immunoreactive proteins were visualized by enhanced chemiluminescent reagents (Thermo Scientific, Rockford, IL, USA). The optical density was quantified by VersaDoc Imaging system (Bio-Rad, Hercules, CA, USA).

Transwell invasion assay. The cells were seeded at a concentration ratio of $5 \times 10^{4}$ cells/chamber in serum-free RPMI-1640 and placed on the $8 \mu \mathrm{m}$ pore-size upper chamber (Corning Incorporated, Corning, NY, USA). The lower chambers contained RPMI-1640 culture media with 10\% FBS. After $24 \mathrm{~h}$ of incubation, non-invading cells on the top chamber were removed by using a cotton swab, and cells that penetrated to the lower surface were fixed with $800 \mu \mathrm{l}$ methanol for $30 \mathrm{~min}$, stained with $0.5 \%$ crystal violet solution for $2 \mathrm{~h}$, washed with 1X PBS and counted under a microscope. Six fields were randomly selected from each sample, with triplicates.

Cell viability assay. Sensitivity of cells to EPI was assayed with the CCK-8 kit. Briefly, cells were seeded in 96-well plates with a density of $1 \times 10^{4} /$ well and incubated for $24 \mathrm{~h}$ at $37^{\circ} \mathrm{C}$ and then treated with EPI $(0.2,1.2,3$ and $6 \mu \mathrm{g} / \mathrm{ml}), \mathrm{Zt} / \mathrm{g} 4$ $(8 \mu \mathrm{g} / \mathrm{ml})$ combined with EPI for $48 \mathrm{~h}$. The proportion of live cells of the two groups was analyzed by CCK-8 kit according to the manufacturer's instructions. Finally, the absorbance (OD) value of each well was measured by a microplate reader at the wavelength of $450 \mathrm{~nm}$. The experiment was carried out in triplicate. Dose-dependent response curve was plotted and the half maximal inhibitory concentration $\left(\mathrm{IC}_{50}\right)$ was determined by fitting the concentration response curves with the sigmaplot software.

Cell cycle analysis. Cell cycle status was detected by flow cytometry and analyzed by Flowjo software. Briefly, after exposed to $\mathrm{Zt} / \mathrm{g} 4$, EPI or both for $24 \mathrm{~h}$, cells $\left(2 \times 10^{5}-10^{6}\right)$ were harvested, fixed with $75 \%$ ethanol overnight at $-20^{\circ} \mathrm{C}$. The fixed cells were incubated in darkness at $37^{\circ} \mathrm{C}$ with $1 \mathrm{mg} / \mathrm{ml}$ RNase A (Sigma-Aldrich, St. Louis, MO, USA) for $30 \mathrm{~min}$ and with $50 \mu \mathrm{g} / \mathrm{ml}$ propidium iodide (PI) (Sigma-Aldrich) for $30 \mathrm{~min}$. The cells were analyzed by flow cytometry (FACScan, Becton-Dickinson, Franklin Lakes, NJ, USA).

Apoptosis analysis. After Zt/g4, EPI or both for $48 \mathrm{~h}$, the cells were collected and washed twice with cold PBS, followed by resuspension in binding buffer at the density of $1 \times 10^{6}$ cells $/ \mathrm{ml}$. $100 \mu \mathrm{l}\left(1 \times 10^{5}\right.$ cells $)$ of the solution was removed and stained 
$\mathbf{A}$

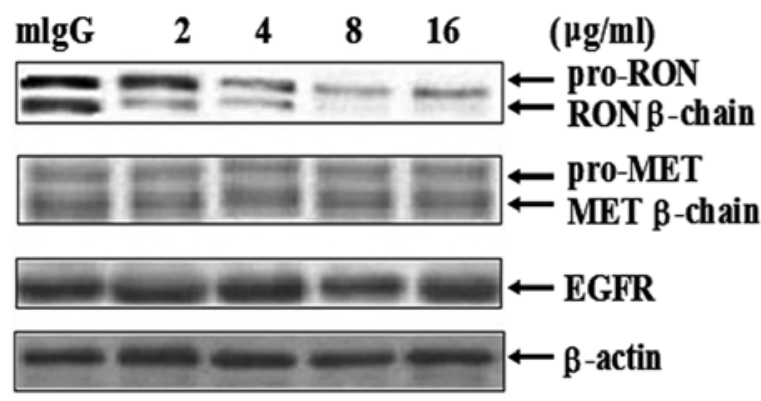

B mlgG $\quad \mathrm{Zt} / \mathbf{g} 4$

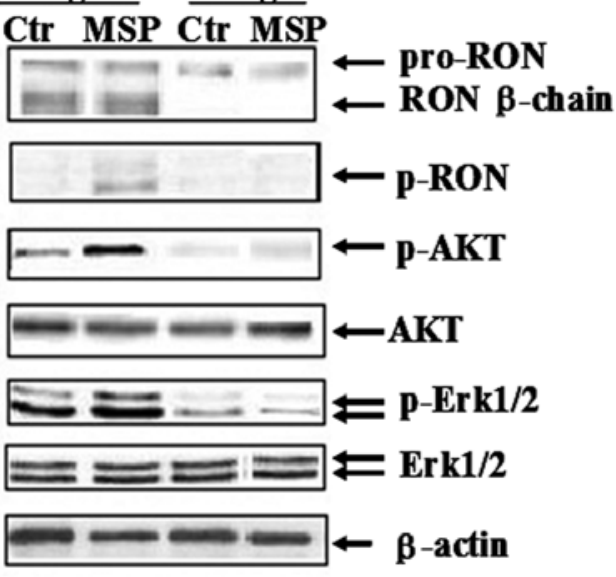

Figure 2. Concentration-dependent downregulation of RON expression after Zt/g4 treatment. (A) Dose-dependent downregulation by Zt/g4 of RON expression. RON expression levels in 5637 cells treated with Zt/g4 at 0, 2, 4, 8 and $16 \mu \mathrm{g} / \mathrm{ml}$ for $24 \mathrm{~h}$, respectively. The levels of RON, MET and EGFR were detected by western blot analysis. (B) Zt/g4 inhibited MSP induced RON activation and downstream signal transduction. Zt/g4 or mIgG (8 $\mu \mathrm{g} / \mathrm{ml}) \mathrm{was}$ added to culture medium for $48 \mathrm{~h}$, then cells were harvested and stimulated by MSP for 30 min, phospho-RON, Erk1/2 and AKT were detected by western blotting.

with $5 \mu$ l Annexin V-FITC and PI (BD Biosciences) for $15 \mathrm{~min}$ in the dark at room temperature. Then a total of 400 dilution buffer was added to each tube and cell apoptosis was analysed by flow cytometry (FACScan, Becton-Dickinson). The percentage of apoptotic cells with Annexin $\mathrm{V}^{+} / \mathrm{PI}^{+}$was evaluated. Each group was measured three times.

Statistical analysis. Statistical analyses were performed using SPSS software (version 18; SPSS Inc., Chicago, IL, USA). Data are presented as the means \pm standard deviation (SD). Statistical significance between two groups was evaluated by Student's t-test. Differences between multiple groups were performed by one-way analysis of variance. A difference was considered significant at $\mathrm{P}<0.05$.

\section{Results}

Expression of RON receptors in bladder cancer cell lines. The expression of RON was detected by western blotting in seven bladder cancer cell lines (Fig. 1). In this panel, 5637, T24 and RT4 cell lines had a high level of RON expression, while the expression levels of RON in other three cancer cell lines were barely found. As the 5637 cells expressed a relatively higher level of RON than those in T24 and RT4 cells, we chose 5637 cells for future studies.

Zt/g4 induces reduction of RON expression and signal inhibition. Western blot analysis confirmed that $\mathrm{Zt} / \mathrm{g} 4$ treatment for 24 h caused diminished RON expression in a dose-dependent manner in 5637 cells (Fig. 2A). When used with $2 \mu \mathrm{g} / \mathrm{ml}$ of $\mathrm{Zt} / \mathrm{g} 4, \mathrm{Zt} / \mathrm{g} 4$-induced reduction of RON $\beta$-chain expression was significantly identified. However, the concentration of $\mathrm{Zt} / \mathrm{g} 4$ increased up to $8 \mu \mathrm{g} / \mathrm{ml}$, but did not further cause $\mathrm{RON}$ reduction. Thus, the maximal effect induced by $\mathrm{Zt} / \mathrm{g} 4$ was at the range of $8 \mu \mathrm{g} / \mathrm{ml}$. We chose this concentration as the standard for further experiments. Cross-talk between RON and MET or EGFR has been found in various cancer cells $(28,29)$. We verified whether $\mathrm{Zt} / \mathrm{g} 4$-induced $\mathrm{RON}$ reduction affected MET or EGFR expression in 5637 cells. Result

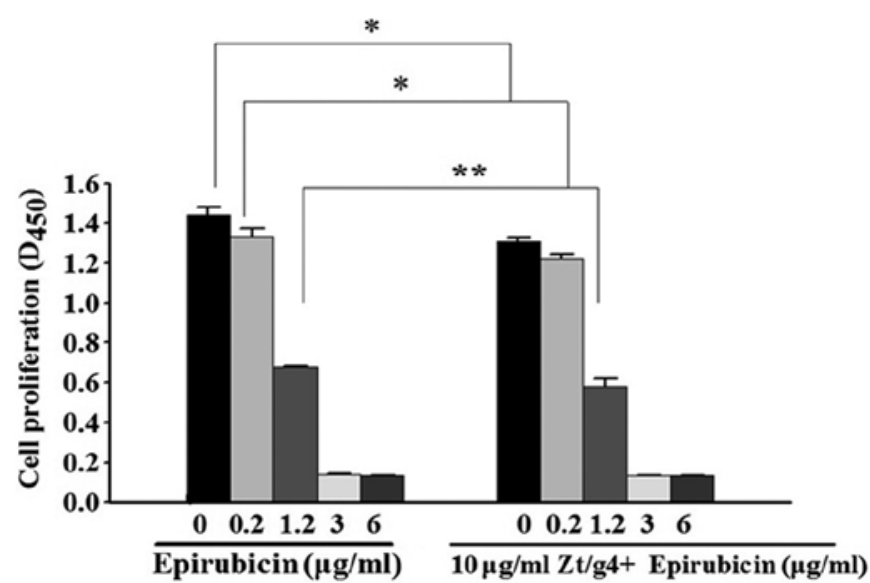

Figure 3. Effects of RON inhibition by $\mathrm{Zt} / \mathrm{g} 4$ on the sensitivity to EPI in 5637 cells. CCK-8 analysis of cell growth inhibiton in EPI and EPI in combination with $\mathrm{Zt} / \mathrm{g} 4$ groups. Values are presented as the means $\pm \mathrm{SD}$ from three independent experiments. ${ }^{*} \mathrm{P}<0.05,{ }^{* *} \mathrm{P}<0.01$.

showed that there were no significant differences in the total level of MET and EGFR expression in 5637 cells after $\mathrm{Zt} / \mathrm{g} 4$ treatment. Taken together, these results demonstrated that $\mathrm{Zt} / \mathrm{g} 4$-induced RON reduction was specific to $\mathrm{RON}$ and had no effect on MET or EGFR.

As MSP was detected in human urine samples (11), MSP induced RON activation and signaling transduction may be a key event in bladder tumorigenesis and invasion. To test whether $\mathrm{Zt} / \mathrm{g} 4$ blocks MSP induced RON activation and downstream signaling transduction, $5 \mathrm{nM}$ MSP was added to induce RON activation with or without $8 \mu \mathrm{g} / \mathrm{ml} \mathrm{Zt/g} 4$ treatment (Fig. 2B). Result showed that after Zt/g4 treatment for $48 \mathrm{~h}$, MSP induced RON activation was completely inhibited. Phosphorylation of downstream signal molecules such as Erk1/2 and AKT were also interrupted (Fig. 2B).

Zt/g4 enhances the chemosensitivity of EPI on 5637 cells. To determine whether inhibition of RON signaling by $\mathrm{Zt} / \mathrm{g} 4$ enhance chemosensitivity of EPI in 5637 cells, a CCK-8 assay 
A mlgG

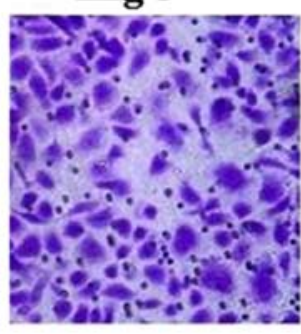

Zt/g4

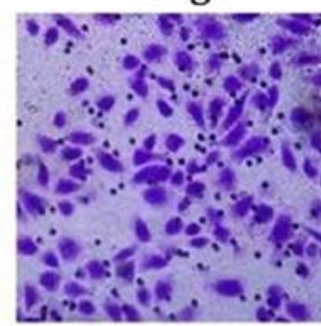

EPI+mlgG

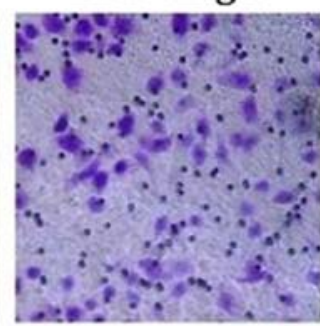

EPI+Zt/g4

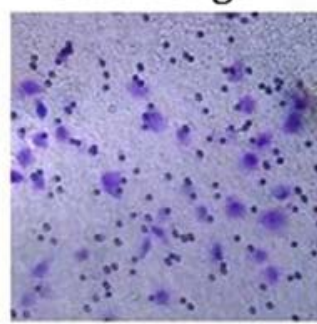

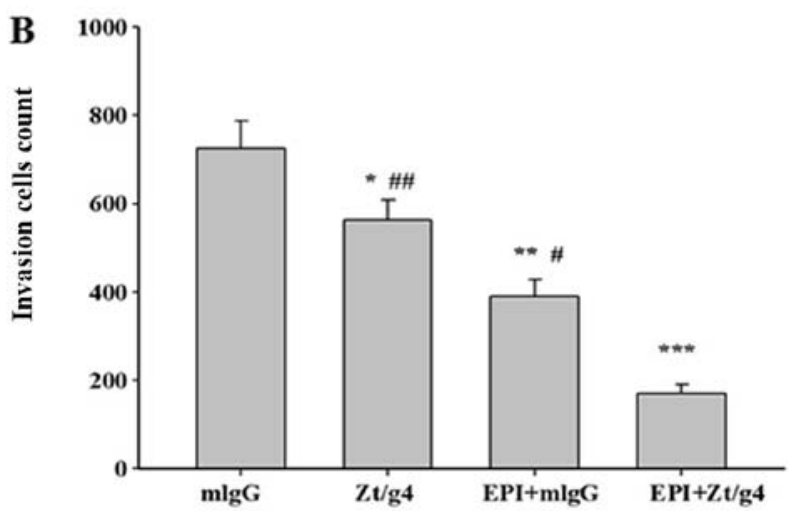

Figure 4. Effect of Zt/g4-induced cell invasion. (A) Representative staining images showing number of perforated cells in $\mathrm{mlgG}, \mathrm{Zt} / \mathrm{g} 4 \mathrm{EPI}+\mathrm{mlgG}$ and $\mathrm{EPI}+\mathrm{Zt} / \mathrm{g} 4$ groups, respectively. (B) Quantitative data of perforated cell number in each group. ${ }^{*} \mathrm{P}<0.05,{ }^{* *} \mathrm{P}<0.01,{ }^{* * * *} \mathrm{P}<0.001$ compared to mlgG group; ${ }^{*} \mathrm{P}<0.05$, ${ }^{\# \#} \mathrm{P}<0.01$, compared to $\mathrm{EPI}+\mathrm{Zt} / \mathrm{g} 4$ group. The data are presented as the means $\pm \mathrm{SD}$ from three independent experiments.


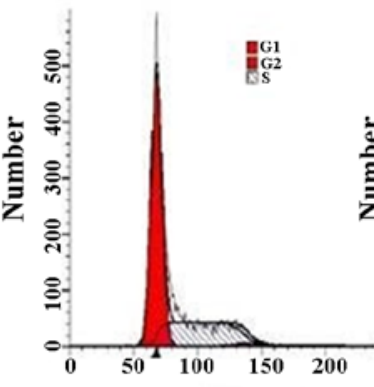

EPI+mlgG

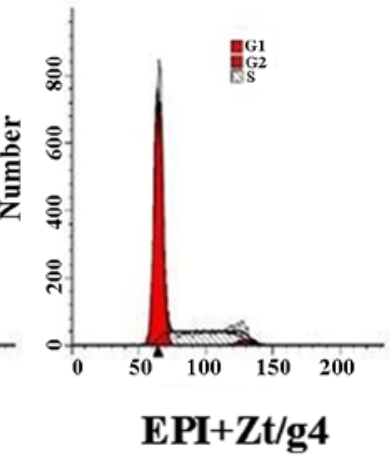

$\mathrm{C}$

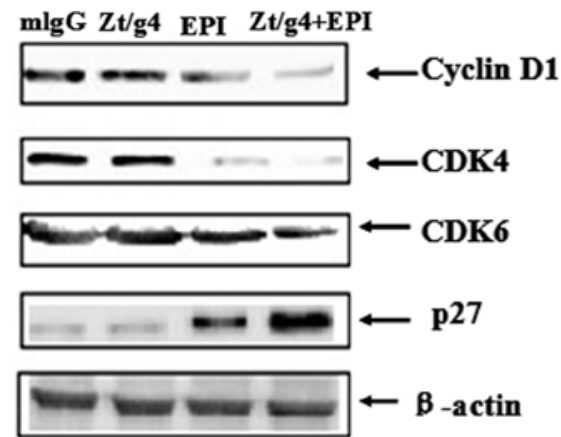

Figure 5. Effects of Zt/g4 on EPI-induced cell cycle in 5637 cells. (A) Changes in cell cycles: 5637 cells were treated at 37C with Zt/g4 alone, EPI alone or both for $24 \mathrm{~h}$, collected, stained with propidium iodide, and then analyzed by flow cytometer. (B) Quantitative analysis of cell cycle distribution of 5637 cells

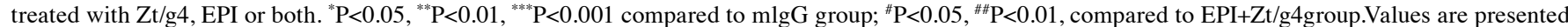
as the means \pm SD from three independent experiments. (C) Representative western blot analysis showed changes in the expression of cyclins (CDK4 and CDK6), cyclin-dependent kinases (cyclin D1) and cyclin-dependent protein kinase inhibitors (p27) following Zt/g4, EPI or combined treatment in 5637 cells. Data represent the mean $\pm S D(n=3)$. 


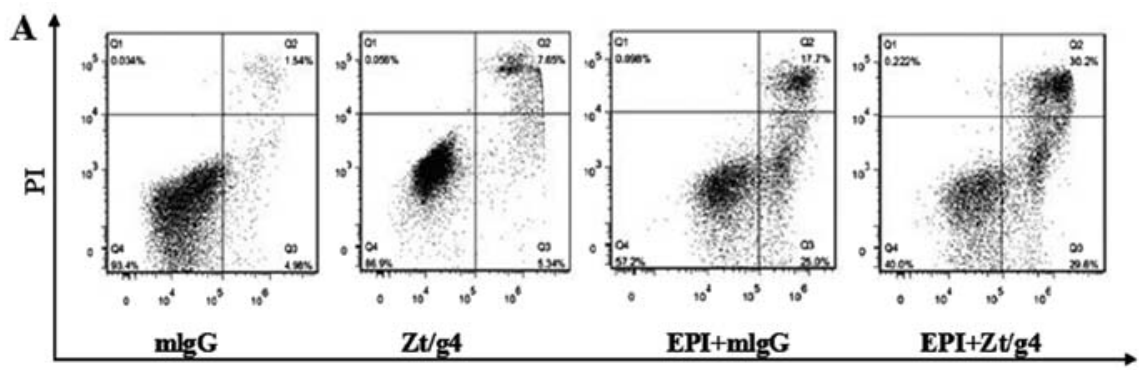

Annexin V-FIrC

C
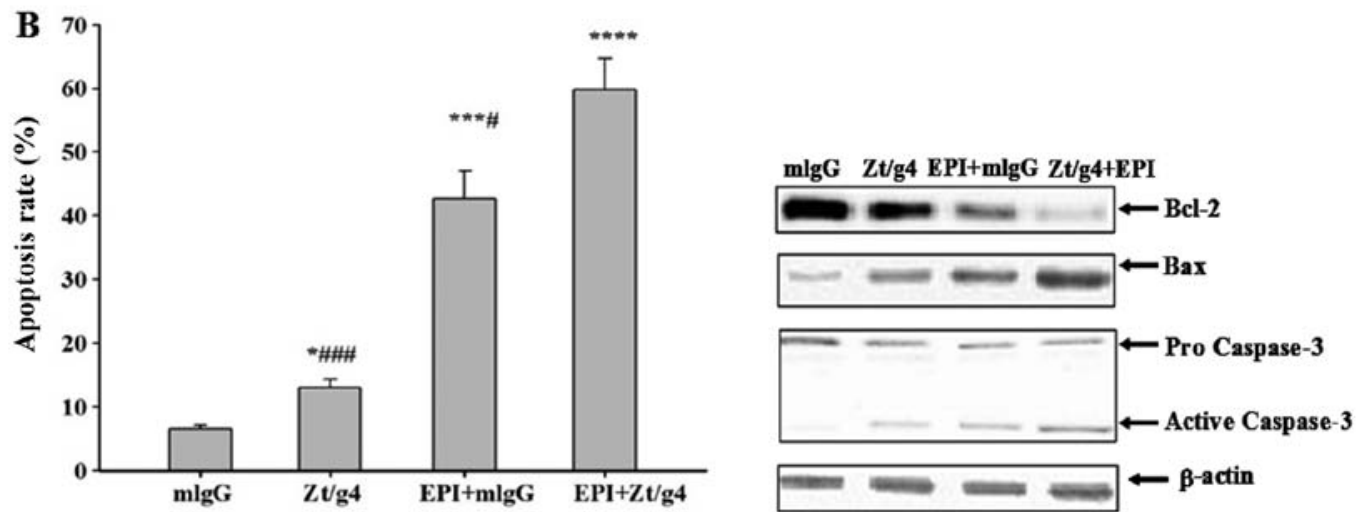

Figure 6. Effects of Zt/g4 on EPI-induced cell apoptosis in 5637 cells. Flow cytometric analysis demonstrated the apoptotic effects of Zt/g4, EPI and both treatment on 5637 cells. (A) Cells were treated with $\mathrm{Zt} / \mathrm{g} 4$, EPI or both for $48 \mathrm{~h}$, collected, stained with Annexin $\mathrm{V}$ and PI and then analyzed by flow cytometer. (B) Quantitative results obtained using Annexin V/PI staining. ${ }^{*} \mathrm{P}<0.05,{ }^{* * *} \mathrm{P}<0.01,{ }^{* * * * *} \mathrm{P}<0.0001$ compared to mlgG group; ${ }^{\#} \mathrm{P}<0.05$, ${ }^{\# \# \#} \mathrm{P}<0.001$, compared to EPI+Zt/g4 group. (C) Representative western blot analysis showed changes in the expression of Bcl-2, Bax and activity-caspase-3 following Zt/g4, EPI or combined treatment in 5637 cells. Data are derived from three independent experiments and are expressed as the mean \pm SD.

was carried out to measure the proliferation status of the cells. 5637 cells were treated with EPI or Zt/g4 combined with EPI at different concentrations. After $48 \mathrm{~h}$, the cell viability was reduced with increasing concentrations of EPI (Fig. 3). The levels of cytotoxicity were indicated as the concentration that inhibits the response by $50 \% \mathrm{IC}_{50}$ value. The $\mathrm{IC}_{50}$ values in $\mathrm{Zt} / \mathrm{g} 4$ combined with EPI and EPI were $(0.9 \pm 0.13,1.2 \pm 0.09)$, respectively. Data showed that RON inhibition by Zt/g4 was able to enhance the sensitivity of 5637 cells to EPI at the concentrations of 0.2 and $1.2 \mu \mathrm{g} / \mathrm{ml}(\mathrm{P}<0.05)$. Since the $\mathrm{IC}_{50}$ value in EPI treated 5637 cells was $(1.2 \pm 0.09 \mu \mathrm{g} / \mathrm{ml})$, the concentration of EPI intervention in subsequent experiments was determined as $1.2 \mu \mathrm{g} / \mathrm{ml}$.

Zt/g4 combining with EPI markedly decreases 5637 cell invasion. Tumor invasion and progression is a common event in NMIBC even after TURBT and intravesical chemotherapy. To study whether combining Zt/g4 and EPI affected cellular invasion, we further carried out Transwell assay on the 5637 cells. The cells were treated with $8 \mu \mathrm{g} / \mathrm{ml} \mathrm{Zt/g} 4$ alone, $1.2 \mu \mathrm{g} / \mathrm{ml}$ EPI alone, EPI combined with $\mathrm{Zt} / \mathrm{g} 4$, or mouse IgG in transmembrane chambers for $24 \mathrm{~h}$. The results showed that the invasive cell count of $\mathrm{Zt} / \mathrm{g} 4$ in combination with EPI was significantly lower than that of $\mathrm{Zt} / \mathrm{g} 4$ or EPI alone (170 $\pm 21 \mathrm{vs}$. $564 \pm 49$ or $390 \pm 37$ individually) (Fig. $4 \mathrm{~A}$ and B), and the cell invasive capacity of the $\mathrm{Zt} / \mathrm{g} 4$ treatment group $(564 \pm 49)$ was significantly lower than the $\mathrm{mlgG}$ group (726 \pm 62 ) (mlgG was used as the control).
Cell cycle arrested at G1/S phase in 5637 cells by Zt/g4 combining with EPI treatment. EPI can often inhibit cell proliferation through induction of cell cycle arrest. To determine whether $\mathrm{Zt} / \mathrm{g} 4$ intracellular delivery of EPI resulted in cell cycle changes, we incubated cells with $\mathrm{Zt} / \mathrm{g} 4$, EPI or both for $24 \mathrm{~h}$ and then examined the DNA content using propidium iodide (PI) staining. The proportions of cells treated with $\mathrm{Zt} / \mathrm{g} 4$ in each phase of the cell cycle showed no significant difference comparing with those of control group. The changes in cellcycle profile were observed after addition of EPI combined with $\mathrm{Zt} / \mathrm{g} 4$, featuring a significant reduction in $\mathrm{S}$ phase, an increase in G1 phase, compared to the EPI treatment alone $(\mathrm{P}<0.05)$ (Fig. 5A and $\mathrm{B})$. These changes were present in all three 5637 cell lines tested. Moreover, we checked several key factors including cyclin D1, CDK4, CDK6 and p27 regulating the G1/S cell cycle transition. The expression of cyclin D1, CDK4, CDK6 and p27was not changed by Zt/g4 treatment in 5637 cells. However, cotreatment of cells with EPI and $\mathrm{Zt} / \mathrm{g} 4$ increased the expression of p27 while downregulated cyclin D1, CDK4 and CDK6 comparing with Zt/g4 or EPI treatment alone (Fig. 5C). These results suggested that the G1/S cell cycle arrest induced by $\mathrm{Zt} / \mathrm{g} 4$ combined with EPI was related with upregulation of the cell cycle inhibitory proteins and downregulation of the cyclin-dependent protein kinases (CDKs) and cyclins.

Zt/g4 combining with EPI treatment promotes apoptosis in 5637 cells. Flow cytometry (FACS) was used to further 
investigate whether $\mathrm{Zt} / \mathrm{g} 4$, EPI or both exerted anticancer effect on 5637 cells through inducing apoptosis. We exposed 5637 cells to $\mathrm{Zt} / \mathrm{g} 4$, EPI or both as previously mentioned, and then stained them with Annexin V-PE and PI to measure apoptosis rates after incubation for $48 \mathrm{~h}$. FACS analysis showed that total apoptosis rates of EPI combined with $\mathrm{Zt} / \mathrm{g} 4$ were significantly increased when comparing with EPI or $\mathrm{Zt} / \mathrm{g} 4$ treatment alone (Fig. 6A and B). This result indicated that $\mathrm{Zt} / \mathrm{g} 4$ was able to promote the EPI-induced apoptosis in 5637 cells. To further unveil the mechanisms by which $\mathrm{Zt} / \mathrm{g} 4$ enhanced EPI-induced apoptosis in 5637 cells, the cells were treated with Zt/g4, EPI or both for $48 \mathrm{~h}$ and subjected to western blot analysis. The bcl-2 protein expression in EPI plus $\mathrm{Zt} / \mathrm{g} 4$ cells was markedly lower while Bax and active caspase-3 protein expression levels were higher than those in the $\mathrm{Zt} / \mathrm{g} 4$ or EPI treatment cells (Fig. 6C). This result suggested that downregulation of RON by $\mathrm{Zt} / \mathrm{g} 4$ promoted EPI induced apoptosis of 5637 cells through mitochondria-mediated apoptotic pathway.

\section{Discussion}

Bladder cancer can be divided into three categories based on its prognosis and management. The first category consists of non-muscle-invasive tumors. The second category consists of muscle invasive bladder cancer (MIBC). The third group is metastasis bladder cancer. Therapeutic aim is different to each of these categories (30). To NMIBC, the main concern is to reduce recurrences and preventing progression to a more advanced stage. TURBT followed by chemotherapy agents and immunotherapy agents are now clinically used to achieve this goal (31). However, even treated with these current approaches, half of NIMBC will recur and progress. More strategies should be investigated to further decrease the rate of NIMBC recurrence and progression.

We and others have found that RON plays an important role in the pathogenesis of bladder cancer $(11,14)$. Although RON is recently reported to associate with the chemosensitivity in human malignancies such as breast cancer and pancreatic cancer $(19,32)$, its role in chemotherapy of bladder cancer remains largely unknown. In this study, our results showed that Ron signaling inhibition by Zt/g4 could remarkably enhance the chemosensitivity of epirubicin (EPI) in human 5637 cells and decrease cell invasion. Possible mechanisms include promotion of cell cycle arrest and induction of Bcl-2 dependent apoptosis.

$\mathrm{Zt} / \mathrm{g} 4$ has unique binding specificity to the RON extracellular domains. Recent studies have shown that $\mathrm{Zt} / \mathrm{g} 4$ is highly effective in downregulation of RON expression by colon, breast and pancreatic cancer cells (26). The binding of $\mathrm{Zt} / \mathrm{g} 4$ to the epitopes either on sema or IPT domains is sufficient to cause RON reduction due to RON internalization and degradation by proteasome (33). In this study, we found the effect of Zt/g4 is concentration-dependent. Significant reduction of RON was seen when using $2 \mu \mathrm{g}$ per $\mathrm{ml}$ of $\mathrm{Zt} / \mathrm{g} 4$ and the maximal effect was at the range of $8 \mu \mathrm{g}$ per ml. However, further increase of $\mathrm{Zt} / \mathrm{g} 4$ up to $16 \mu \mathrm{g}$ per $\mathrm{ml}$ did not show additional effect (Fig. 2A). In a recent study, Li reported that the maximal rate of $\mathrm{Zt} / \mathrm{g} 4$ was $10 \mu \mathrm{g}$ per $\mathrm{ml}$ in colon SW620 cells (26). The maximal effect is related to the amounts of $\mathrm{Zt} / \mathrm{g} 4$ that bind to RON extracellular domain. Cross-talk between RON and MET or EGFR exist on the cell membrane surface, and specifically blocking RON is under intensive investigation $(28,29)$. In the present study, the effect of $\mathrm{Zt} / \mathrm{g} 4$ was only specific to RON. It had no effect on the structurally-related MET or unrelated EGFR in Fig. 2B. Moreover, after persistent $\mathrm{Zt} / \mathrm{g} 4$ treatment, MSP induced RON activation was completely inhibited also the downstream pMAPK and pAkt activation was inhibited in 5637 cells.

Cancer cell unlimited growth and invasion are the most fatal features of malignant tumors, accounting for $>90 \%$ of tumor-related mortality (34). Overexpression of RON contributes to increased cell growth and invasion $(35,36)$. The results of this study showed that $\mathrm{Zt} / \mathrm{g} 4$ or EPI alone could moderately inhibit cell proliferation and invasion in 5637 cells, but when $\mathrm{Zt} / \mathrm{g} 4$ was used in combination with EPI it showed significant inhibition of cell proliferation (Fig. 3)and invasion (Fig. 4). Without $\mathrm{Zt} / \mathrm{g} 4, \mathrm{IC}_{50}$ of EPI to 5637 cells was $1.2 \pm 0.09 \mu \mathrm{g} / \mathrm{ml}$ per $10^{5}$ cells, after combining with $\mathrm{Zt} / \mathrm{g} 4, \mathrm{IC}_{50}$ of EPI to 5637 cells was markedly decreased to $0.9 \pm 0.13 \mu \mathrm{g} / \mathrm{ml}$ per $10^{5}$ cells Therefore, $\mathrm{Zt} / \mathrm{g} 4$ was efficient in enhancing chemosensitivity of EPI.

It was documented recently that $\mathrm{Zt} / \mathrm{g} 4$ intracellular delivery of maytansinoid could result in cell cycle changes, suggesting that cell cycle arrest might contribute to enhancement of chemosensitivity by Zt/g4 (37). Therefore, we analyzed the cell cycle distribution of EPI-treated 5637 cells. EPI alone moderately affected cell cycle distribution in the cells, but when it was combined with Zt/g4, an obvious G1/S arrest was found (Fig. 5). Thus, Zt/g4-targeted delivery of EPI affects the cell cycle in 5637 cells. The cyclin-dependent kinases (CDKs) and cyclins play a crucial role in the regulation of cell cycle progression $(38,39)$. The G1 cyclin-CDK complex cyclin D-CDK4/6 is required for S phase entry (40). CDK inhibitors (CKIs) such as p21CIP1/WAF1 and p27KIP1 bind to cyclin-CDK complexes and render them inactive, which inhibit cell cycle progression (41). In our study, we found that cotreatment of Zt/g4 and EPI leads to G1/S arrest into 5637 cells (Fig. 5A and B), which is accompanied by the downregulation of cyclin D1, CDK4 and CDK6, whereas it increased the level of P27 (Fig. 5C).

Apoptosis is a defensive mechanism of the body against the progression and development of tumor. Several studies have suggested that RON is associated with apoptosis in various cancer cells $(42,43)$. However, the impact of RON on apoptosis in human bladder cancer is not reported. Thus, investigating the effect of Zt/g4 on EPI-induced cell apoptosis in 5637 cells is highly desirable. Our experiments showed that EPI-treated 5637 cells exhibited an increase in Annexin V(+)/PI(-) staining, and combined with $\mathrm{Zt} / \mathrm{g} 4$ treatment strengthened this effect, indicating that $\mathrm{Zt} / \mathrm{g} 4$ promoted EPI induced apoptosis (Fig. 6B). The mitochondrial apoptotic pathway is mainly mediated by proteins of the Bcl-2 family such as Bcl-2 and Bax (44). Bcl-2 is an anti-apoptotic protein, which negatively regulates the activation of caspase- 3 that acted as an effector of mammalian cell death pathways (45). Bax is a proapoptotic protein, and the activation of Bax can increase the mitochondrial permeability and the release of pro-apoptotic molecules such as cytochrome-c. Releasing of cytochrome c can active caspase- 3 and leads finally to apoptosis (46). In this 
study, combining EPI and Zt/g4 significantly decreased the protein expression levels of $\mathrm{Bcl}-2$ while increased the protein expression levels of Bax and cleaved caspase-3, suggesting $\mathrm{Zt} / \mathrm{g} 4$ promoted EPI-induced apoptosis via the mitochondrialdependent pathway.

In summary, the results of this study demonstrated that inhibition of RON signaling pathway by $\mathrm{Zt} / \mathrm{g} 4$ markedly improved chemosensitivity of EPI in bladder cancer cells. Both cell proliferation and invasion were effectively inhibited by combining $\mathrm{Zt} / \mathrm{g} 4$ and EPI treatment. Possible mechanisms underlying this combination include induction of cell cycle arrested at G1/S and promotion of mitochondrial pathway of apoptosis. These data provide new strategies to prevent recurrence and progression, which may further improve clinical outcomes of current approaches in treatment with NMIBC.

\section{Acknowledgements}

This study was supported by the National Natural Science Foundation of China (grant no. 81272828 to Q.M., and no. 31501113 to R.Y.), Zhejiang Provincial Foundation for Medical and Health Sciences (grant no. 2016KYB263 and 2014KYB355 to Q.M.), and Ningbo Natural Science Foundation (grant no. 2015A610224 to J.-F.C. and no. 2015A610177 to R.Y.).

\section{References}

1. Siegel RL, Miller KD and Jemal A: Cancer statistics, 2016. CA Cancer J Clin 66: 7-30, 2016.

2. Parekh DJ, Bochner BH and Dalbagni G: Superficial and muscleinvasive bladder cancer: Principles of management for outcomes assessments. J Clin Oncol 24: 5519-5527, 2006.

3. Porten SP, Leapman MS and Greene KL: Intravesical chemotherapy in non-muscle-invasive bladder cancer. Indian J Urol 31: 297-303, 2015

4. Herr HW, Dotan Z, Donat SM and Bajorin DF: Defining optimal therapy for muscle invasive bladder cancer. J Urol 177: 437-443, 2007.

5. Babjuk M, Oosterlinck W, Sylvester R, Kaasinen E, Böhle A, Palou-Redorta $\mathrm{J}$ and Rouprêt $\mathrm{M}$; European Association of Urology (EAU): EAU guidelines on non-muscle-invasive urothelial carcinoma of the bladder, the 2011 update. Eur Urol 59: 997-1008, 2011.

6. Oosterlinck W, Kurth KH, Schröder F, Bultinck J, Hammond B and Sylvester R: A prospective European Organization for Research and Treatment of Cancer Genitourinary Group randomized trial comparing transurethral resection followed by a single intravesical instillation of epirubicin or water in single stage Ta, T1 papillary carcinoma of the bladder. J Urol 149: 749-752, 1993.

7. Yu R, Yu BX, Chen JF, Lv XY, Yan ZJ, Cheng Y and Ma Q Anti-tumor effects of Atractylenolide I on bladder cancer cells. J Exp Clin Cancer Res 35: 40, 2016.

8. Ronsin C, Muscatelli F, Mattei MG and Breathnach R: A novel putative receptor protein tyrosine kinase of the met family. Oncogene 8: 1195-1202, 1993.

9. Park YL, Lee GH, Kim KY, Myung E, Kim JS, Myung DS, Park KJ, Cho SB, Lee WS, Jung YD, et al: Expression of RON in colorectal cancer and its relationships with tumor cell behavior and prognosis. Tumori 98: 652-662, 2012.

10. Feres KJ, Ischenko I and Hayman MJ: The RON receptor tyrosine kinase promotes MSP-independent cell spreading and survival in breast epithelial cells. Oncogene 28: 279-288, 2009.

11. Cheng HL, Liu HS, Lin YJ, Chen HH, Hsu PY, Chang TY, Ho CL, Tzai TS and Chow NH: Co-expression of RON and MET is a prognostic indicator for patients with transitional-cell carcinoma of the bladder. Br J Cancer 92: 1906-1914, 2005.

12. Catenacci DV, Cervantes G, Yala S, Nelson EA, El-Hashani E, Kanteti R, El Dinali M, Hasina R, Brägelmann J, Seiwert T, et al: RON (MST1R) is a novel prognostic marker and therapeutic target for gastroesophageal adenocarcinoma. Cancer Biol Ther 12: 9-46, 2011
13. Ren X, Daa T, Yada N, Kashima K, Fujitomi Y and Yokoyama S: Expression and mutational status of RON in neoplastic lesions of the breast: Analysis of MSP/RON signaling in ductal carcinoma in situ and invasive ductal carcinoma. APMIS 120: 358-367, 2012.

14. Wang MH, Lee W, Luo YL, Weis MT and Yao HP: Altered expression of the RON receptor tyrosine kinase in various epithelial cancers and its contribution to tumourigenic phenotypes in thyroid cancer cells. J Pathol 213: 402-411, 2007.

15. Wang MH, Kurtz AL and Chen Y: Identification of a novel splicing product of the RON receptor tyrosine kinase in human colorectal carcinoma cells. Carcinogenesis 21: 1507-1512, 2000.

16. Eckerich C, Schulte A, Martens T, Zapf S, Westphal M and Lamszus K: RON receptor tyrosine kinase in human gliomas: Expression, function, and identification of a novel soluble splice variant. J Neurochem 109: 969-980, 2009.

17. Ma Q, Zhang K, Guin S, Zhou YQ and Wang MH: Deletion or insertion in the first immunoglobulin-plexin-transcription (IPT) domain differentially regulates expression and tumorigenic activities of RON receptor Tyrosine Kinase. Mol Cancer 9: 307, 2010.

18. Yao HP, Zhou YQ, Zhang R and Wang MH: MSP-RON signalling in cancer: Pathogenesis and therapeutic potential. Nat Rev Cancer 13: 466-481, 2013.

19. Prislei S, Mariani M, Raspaglio G, Mozzetti S, Filippetti F, Ferrandina G, Scambia G and Ferlini C: RON and cisplatin resistance in ovarian cancer cell lines. Oncol Res 19: 13-22, 2010.

20. Yao HP, Zhou YQ, Ma Q, Guin S, Padhye SS, Zhang RW and Wang MH: The monoclonal antibody $\mathrm{Zt} / \mathrm{f} 2$ targeting RON receptor tyrosine kinase as potential therapeutics against tumor growth-mediated by colon cancer cells. Mol Cancer 10: 82-93, 2011.

21. Xu XM, Wang D, Shen Q, Chen YQ and Wang MH: RNA-mediated gene silencing of the RON receptor tyrosine kinase alters oncogenic phenotypes of human colorectal carcinoma cells. Oncogene 23: 8464-8474, 2004

22. Yao HP, Zhuang CM, Zhou YQ, Zeng JY, Zhang RW and Wang MH: Oncogenic variant RON160 expression in breast cancer and its potential as a therapeutic target by small molecule tyrosine kinase inhibitor. Curr Cancer Drug Targets 13: 686-697, 2013.

23. Hsu PY, Liu HS, Cheng HL, Tzai TS, Guo HR, Ho CL and Chow NH: Collaboration of RON and epidermal growth factor receptor in human bladder carcinogenesis. J Urol 176: 2262-2267, 2006.

24. Guin S, Yao HP and Wang MH: RON receptor tyrosine kinase as a target for delivery of chemodrugs by antibody directed pathway for cancer cell cytotoxicity. Mol Pharm 7: 386-397, 2010.

25. Guin S, Ma Q, Padhye S, Zhou YQ, Yao HP and Wang MH: Targeting acute hypoxic cancer cells by doxorubicin-immunoliposomes directed by monoclonal antibodies specific to RON receptor tyrosine kinase. Cancer Chemother Pharmacol 67: 1073-1083, 2011

26. Li Z, Yao H, Guin S, Padhye SS, Zhou YQ and Wang MH: Monoclonal antibody (mAb)-induced down-regulation of RON receptor tyrosine kinase diminishes tumorigenic activities of colon cancer cells. Int J Oncol 37: 473-482, 2010.

27. Padhye SS, Guin S, Yao HP, Zhou YQ, Zhang R and Wang MH: Sustained expression of the RON receptor tyrosine kinase by pancreatic cancer stem cells as a potential targeting moiety for antibody-directed chemotherapeutics. Mol Pharm 8: 2310-2319, 2011.

28. Follenzi A, Bakovic S, Gual P, Stella MC, Longati P and Comoglio PM: Cross-talk between the proto-oncogenes Met and Ron. Oncogene 19: 3041-3049, 2000.

29. Peace BE, Hill KJ, Degen SJ and Waltz SE: Cross-talk between the receptor tyrosine kinases Ron and epidermal growth factor receptor. Exp Cell Res 289: 317-325, 2003.

30. Clark PE, Agarwal N, Biagioli MC, Eisenberger MA, Greenberg RE, Herr HW, Inman BA, Kuban DA, Kuzel TM, Lele SM, et al; National Comprehensive Cancer Network (NCCN): Bladder cancer. J Natl Compr Canc Netw 11: 446-475, 2013.

31. Babjuk M, Burger M, Zigeuner R, Shariat SF, van Rhijn BW, Compérat E, Sylvester RJ, Kaasinen E, Böhle A, Palou Redorta J, et al; European Association of Urology: EAU guidelines on non-muscle-invasive urothelial carcinoma of the bladder: Update 2013. Eur Urol 64: 639-653, 2013.

32. Logan-Collins J, Thomas RM, Yu P, Jaquish D, Mose E, French R, Stuart W, McClaine R, Aronow B, Hoffman RM, et al: Silencing of RON receptor signaling promotes apoptosis and gemcitabine sensitivity in pancreatic cancers. Cancer Res 70: $1130-1140,2010$ 
33. Yao HP, Luo YL, Feng L, Cheng LF, Lu Y, Li W and Wang MH: Agonistic monoclonal antibodies potentiate tumorigenic and invasive activities of splicing variant of the RON receptor tyrosine kinase. Cancer Biol Ther 5: 1179-1186, 2006.

34. Jin X, Zhu Z and Shi Y: Metastasis mechanism and gene/protein expression in gastric cancer with distant organs metastasis. Bull Cancer 101: E1-E12, 2014.

35. Wagh PK, Peace BE and Waltz SE: Met-related receptor tyrosine kinase Ron in tumor growth and metastasis. Adv Cancer Res 100 $1-33,2008$

36. Camp ER, Liu W, Fan F, Yang A, Somcio R and Ellis LM: RON, a tyrosine kinase receptor involved in tumor progression and metastasis. Ann Surg Oncol 12: 273-281, 2005.

37. Feng L, Yao HP, Wang W, Zhou YQ, Zhou J, Zhang R and Wang MH: Efficacy of anti-RON antibody Zt/g4-drug maytansinoid conjugation (Anti-RON ADC) as a novel therapeutics for targeted colorectal cancer therapy. Clin Cancer Res 20: 6045-6058, 2014.

38. Morgan DO: Cyclin-dependent kinases: Engines, clocks, and microprocessors. Annu Rev Cell Dev Biol 13: 261-291, 1997.

39. Murray AW and Marks D: Can sequencing shed light on cell cycling? Nature 409: 844-846, 2001.
40. Connell-Crowley L, Elledge SJ and Harper JW: G1 cyclindependent kinases are sufficient to initiate DNA synthesis in quiescent human fibroblasts. Curr Biol 8: 65-68, 1998

41. Vermeulen K, Van Bockstaele DR and Berneman ZN: The cell cycle: A review of regulation, deregulation and therapeutic targets in cancer. Cell Prolif 36: 131-149, 2003.

42. Chung CY, Park YL, Song YA, Myung E, Kim KY, Lee GH, Ki HS, Park KJ, Cho SB, Lee WS, et al: Knockdown of RON inhibits AP-1 activity and induces apoptosis and cell cycle arrest through the modulation of Akt/FoxO signaling in human colorectal cancer cells. Dig Dis Sci 57: 371-380, 2012.

43. Song YA, Park YL, Kim KY, Myung E, Chung CY, Cho SB Lee WS, Jung YD, Kweon SS and Joo YE: RON is associated with tumor progression via the inhibition of apoptosis and cell cycle arrest in human gastric cancer. Pathol Int 62: 127-136, 2012.

44. Brunelle JK and Letai A: Control of mitochondrial apoptosis by the Bcl-2 family. J Cell Sci 122: 437-441, 2009.

45. Nakashima T, Miura M and Hara M: Tetrocarcin A inhibits mitochondrial functions of Bcl-2 and suppresses its anti-apoptotic activity. Cancer Res 60: 1229-1235, 2000

46. Wong RS: Apoptosis in cancer: From pathogenesis to treatment. J Exp Clin Cancer Res 30: 87, 2011. 